\title{
Differential effects of spring reacclimation and deacclimation on cell membranes of Norway spruce seedlings
}

\author{
Paweł M. Pukacki*, Emilia Kamińska-Rożek \\ Physiology of Abiotic Stress Laboratory, Institute of Dendrology, Polish Academy of Sciences, Parkowa 5, 62-035 Kórnik, Poland
}

\section{Abstract}

Two-year-old seedlings of Norway spruce (Picea abies) during spring deacclimation were subjected to controlled reacclimation by exposure to low temperatures of $4 /-3^{\circ} \mathrm{C}$ (day/night) in a cold room. The highest increase in freezing tolerance $\left(\right.$ by $\left.7{ }^{\circ} \mathrm{C}\right)$ was observed after $12 \mathrm{~d}$ of low temperature exposure, when shoot water potential $\left(\Psi_{w \text { shoot }}\right)$ decreased to $0.64 \mathrm{MPa}$. The process of reacclimation was accompanied by an increase in the phospholipid content of needle cell membranes. This increase applied to total (PL) and individual phospholipids: phosphatidylcholine (PC), phosphatidylglycerol (PG), phosphatidylethanolamine (PE) and phosphatidic acid (PA). After being exposed to the low temperature for $18 \mathrm{~d}$, the seedlings were moved into the open air. This caused deacclimation, with an increase in $\Psi_{\text {w shoot }}$ to $-0.36 \mathrm{MPa}$ and a decrease in the total phospholipid content and freezing tolerance of the needles. Significant correlations were observed between freezing tolerance, the membrane permeability (MP) of the needles and the phospholipid content, $\Psi_{\text {w shoot }}$ and water content of the needles. The results show that during spring deacclimation, Norway spruce seedlings can be subjected to reacclimation, which is reflected in the phospholipid content, the biophysical changes of the membranes, and the freezing tolerance of the seedlings. During both spring deacclimation and reacclimation, water content in the needles plays a critical role in the cold tolerance of spruce seedlings.

Keywords: freezing tolerance, membrane permeability, phospholipids, Picea abies, deacclimation, reacclimation

\section{Introduction}

Plant tolerance to freezing is genetically conditioned to a large extent, but it is also dynamic, changing seasonally [1,2]. Environmental factors, such as temperature, water deficit, and light, regulate the cellular level of expression of genes associated with plant dormancy, cold hardiness, and development. After growth cessation, mainly under the influence of short days, tree buds begin endodormancy [3], which is transformed into ecodormancy, mainly due to low temperatures. At the end of winter, day length and mean air temperatures increase, while freezing tolerance declines, gradually releasing ecodormancy [4]. This release starts the process of deacclimation in trees. There is little information about the early stages of spring deacclimation/reacclimation. The reaction to exposure deacclimation, warm temperatures and light is dependent upon the species. Woody plants exhibit two forms of deacclimation: "active" and "passive". Active deacclimation occurs in spring

* Corresponding author. Email: ppukacki@man.poznan.pl

Handling Editor: Grażyna Kłobus

This is an Open Access digital version of the article distributed under the terms of the Creative Commons Attribution 3.0 License (creativecommons.org/licenses/by/3.0/), which permits redistribution, commercial and non-commercial, provided that the article is properly cited. and is associated with the resumption of growth. Passive deacclimation results from the exposure of fully acclimated plants in mid-winter to $5^{\circ} \mathrm{C}$ or higher temperatures. Some researchers suggest that the reversal process, reacclimation, can be observed during deacclimation in spring [3]. During reacclimation, the return to tolerance levels similar to those observed in mid-winter is impossible, as was observed in Scots pine $[4,5]$. Reacclimation potential decreases with increasing deacclimation duration. In trees of boreal forests, the process of acclimation in autumn is slower (weeks to months) than spring deacclimation (days to a week). In tree seedlings grown under controlled conditions, both acclimation and deacclimation can be successfully initiated. The strongest effects of acclimation in evergreen conifers are observed in autumn [2,6,7]. Our first study on multiple acclimation and deacclimation of current-year Norway spruce shoots was carried out in mid-winter [8]. During deep dormancy, spruce shoots were successively deacclimated and again acclimated by subjecting them first to temperatures of $22^{\circ} \mathrm{C}$ and $15^{\circ} \mathrm{C}$ and long days, followed by a temperature of $1^{\circ} \mathrm{C}$ and short days, reaching a level of freezing tolerance similar to the initial level $[5,9]$. However, successful full deacclimation/ reacclimation was possible only until the end of February [9]. The major sites of biochemical transformations, as well as of freezing injuries in the needles of coniferous trees, are cytoplasmic membranes [10]. The composition of phospholipids and polyunsaturated fatty acids affects the biophysical state of membranes (phase structure), and this determines membrane permeability to ions $[6,11]$. In autumn, with the progress of acclimation, membrane permeability to water increases. 
In their studies, Siminowitch et al. [12], Senser and Beck [13,14], and Iivonen et al. [15] demonstrated a correlation between the level of plant acclimation and the phospholipid content of the tissues. Needles of acclimated seedlings of Pinus sylvestris had higher phospholipid content than non-acclimated ones [16]. These investigations have been considerably extended by other studies [17-19]. These studies observed a clear relationship between the process of acclimation and the concentrations of phospholipids, such as phosphatidylcholine (PC) and phosphatidylethanolamine (PE). There are some signals that appear in the coniferous species Picea glauca, Pinus banksiana and Pinus contorta during plant deacclimation in spring, including increasing day length and air temperature and a gradual decrease in the concentrations of phospholipids, polyunsaturated fatty acids, sugars and proteins, which accumulated during acclimation in autumn $[20,21]$.

In many parts of the northern hemisphere, cold snaps in late winter and early spring, when the process of deacclimation begins, are particularly dangerous for trees [22]. Extreme frost injury in late winter after warm periods and after late spring frosts has often been recorded in Poland when the temperature drops below $-8.0^{\circ} \mathrm{C}$ in April [23]. In late winter and early spring, temperature variation (day/night) is accompanied by lowered humidity, which leads to a strong water deficit in the photosynthetic organs of evergreen trees.

The aim of this study was to investigate the ability of spruce seedlings during spring deacclimation to respond to changes in cold hardiness during reacclimation caused by temperature variations simulating the late winter and early spring periods. The study focused on how the disturbance of deacclimation by the process of induced reacclimation is reflected in the water relation, individual phospholipid content, free fatty acid content and the biophysical properties of cytoplasmic membranes in spruce needles.

\section{Material and methods}

\section{Plant material}

Two-year-old Norway spruce seedlings [Picea abies (L.) Karst.] of the submontane provenance Węgierska Górka $\left(49^{\circ} 34^{\prime} \mathrm{N}, 19^{\circ} 10^{\prime} \mathrm{E}, 750 \mathrm{~m}\right.$ a.s.l.) were obtained in March from a forest nursery in the Konstantynowo Forest District (near Poznan, Poland). The seedlings were transferred from the nursery to plastic boxes containing a perlite: peat mixture (1:5, $\mathrm{v}: \mathrm{v})$ and were then split into blocks and replicates. One portion of the seedlings was subjected to a reacclimation treatment at $4 /-3^{\circ} \mathrm{C}$ day/night for $18 \mathrm{~d}$ (April 10-28). These seedlings were stored in a cold room at a relative humidity of $52 \%$ with day length increasing from 14 to 16 hours, simulating the outdoors, at $50 \mu \mathrm{mol} \mathrm{m}^{-2} \mathrm{~s}^{-1}$ of photon flux density. To minimize soil freezing during the cold nights, the pots were placed in insulated boxes. On the 18th day of the experiment, the reacclimated plants were transferred outdoors and kept with the control seedlings (Fig. 1b). During the reacclimation treatment, the control seedlings of the same provenance were kept outdoors under the canopy of trees. The entire experiment lasted from April 10 until May 22.

\section{Determination of freezing tolerance}

Changes in the freezing tolerance of the needles during reacclimation cycles were measured using the method of
Pukacki and Pukacka [10]. Needles from current-year spruce shoots were placed in test tubes in a computer-controlled freezer (Binder MK 53, Germany). After $0.5 \mathrm{~h}$ equilibration at $0^{\circ} \mathrm{C}$, the temperature was decreased at a rate of $0.05^{\circ} \mathrm{C} \mathrm{min}^{-1}$. The needle samples were withdrawn at $5^{\circ} \mathrm{C}$ intervals and allowed to thaw at $3^{\circ} \mathrm{C}$ overnight. After freezing, the needles were thawed at a rate of $0.07^{\circ} \mathrm{C} \mathrm{min}{ }^{-1}$. The needles were then placed into distilled water $\left(0.1 \mathrm{~g} \mathrm{ml}^{-1}\right)$. The percentage of ion leakage from the samples was determined by measuring its electrical conductivity of the solution after incubation for $24 \mathrm{~h}$ at room temperature. The conductivity was measured using a temperature-compensating conductivity meter (CPC-551, Elmetron, Poland). To measure total conductivity, the samples were killed by freezing at $-60^{\circ} \mathrm{C}$ for $80 \mathrm{~min}$, after which they were re-extracted for $24 \mathrm{~h}$ at room temperature in the original solution. The cold hardiness of needles was defined as the lethal temperature $\left(L T_{50}\right)$ and was calculated as the temperature producing $50 \%$ ion leakage.

\section{Membrane permeability (MP)}

The level of MP to ions was expressed as the conductivity of the leakage from the needles. Samples ( $1 \mathrm{~g}$ each) of spruce needles were soaked in distilled water $(1: 10, \mathrm{w}: \mathrm{v})$. The conductivity of the solution was measured after incubation for $48 \mathrm{~h}$, according to Zwiazek and Shay [24]. The specific ion leakage from the needles in siemens (S) per gram fresh weight $\left(\mu \mathrm{S} \mathrm{g}{ }^{-1} F W\right)$ was used as an indicator of membrane permeability.

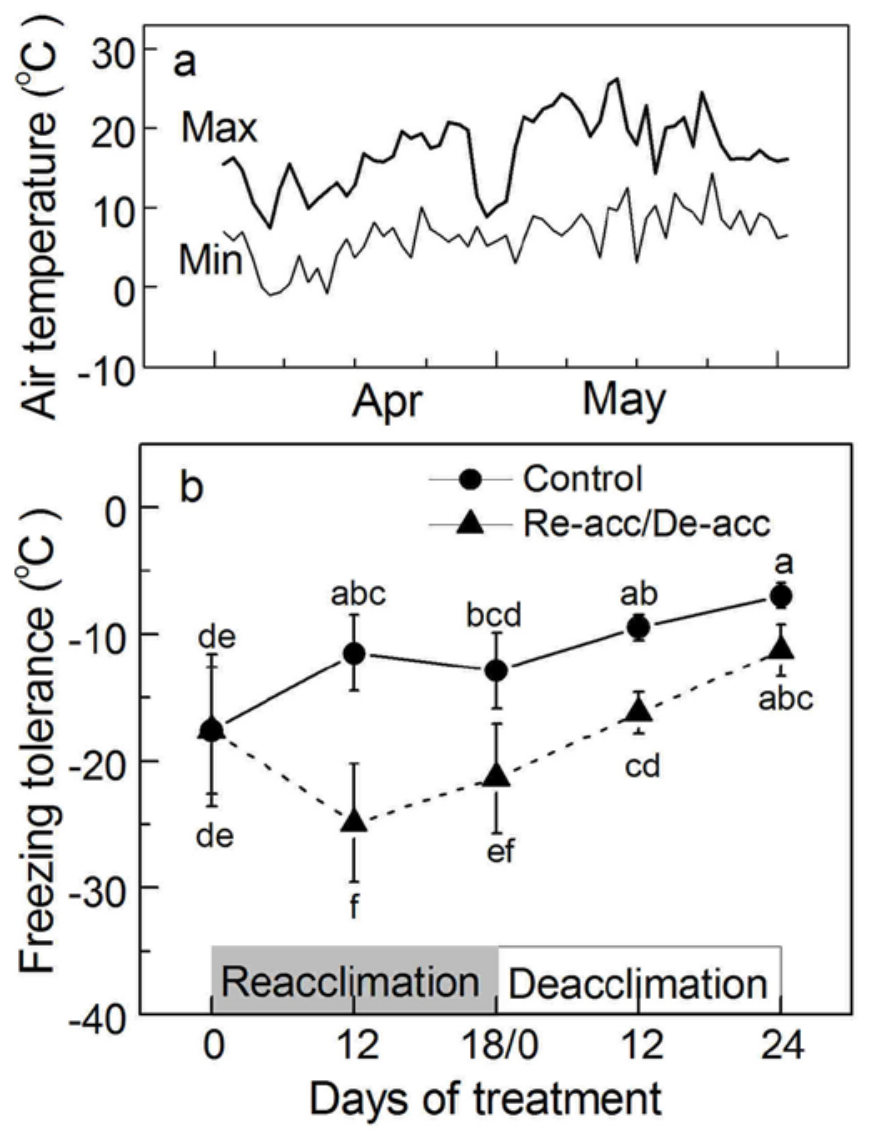

Fig. 1 The maximum and minimum air temperatures (a) in Kórnik $\left(52^{\circ} 15^{\prime} \mathrm{N}, 17^{\circ} 04^{\prime} \mathrm{E}\right)$, measured approximately $200 \mathrm{~m}$ away from the experimental site (70 $\mathrm{m}$ altitude), and the effects of reacclimation (Reacc) and deacclimation (De-acc) on the freezing tolerance of needles $\left(L T_{50} ; \mathbf{b}\right)$. Mean values $\pm S D(n=5)$. Significant differences (according to the Duncan test, $P<0.05)$ are indicated by different letters. 


\section{Measurement of water relation}

The water potentials of the shoot $\left(\Psi_{w \text { shoot }}\right)$ were measured using a pressure bomb (PMS) instrument (Corvalis, USA) according to a previously described method [25].

The measurements were repeated every $3 \mathrm{~d}$. When $\Psi_{\text {w shoot }}$ decreased to $-0.64 \mathrm{MPa}$ (which occurred after $12 \mathrm{~d}$ of reacclimation and $-0.72 \mathrm{MPa}$ (after $18 \mathrm{~d}$ of reacclimation), biochemical analyses were performed that measured the following: phospholipids, a-tocopherol, sterols, free fatty acids, malondialdehyde, and freezing tolerance. After the transfer of the seedlings to field conditions, when $\Psi_{\text {w shoot }}$ increased to $-0.50 \mathrm{MPa}$ (after $12 \mathrm{~d}$ of deacclimation) and $-0.36 \mathrm{MPa}$ (after $24 \mathrm{~d}$ of deacclimation), the above analyses were repeated.

The water content $(W C)$ of the needles was expressed in terms of the percentage of fresh weight using the following equation: $W C=(F W-D W) / D W ; D W-$ dry weight. The samples were dried at $74^{\circ} \mathrm{C}$ for $72 \mathrm{~h}$.

\section{Lipid peroxidation}

The level of lipid peroxidation in the needles was measured as malondialdehyde (MDA) formation and determined by means of reaction with thiobarbituric acid (TBA), according to Heath and Packer [26]. The needles were ground in a cold mortar using 5\% trichloroacetic acid (TCA). The homogenate was centrifuged at $12000 \mathrm{~g}$ for $15 \mathrm{~min}$. A $1000 \mu \mathrm{l}$ aliquot of $2 \mathrm{ml}$ $0.5 \%(\mathrm{w} / \mathrm{v})$ TBARS containing $20 \%$ TCA was added to $200 \mu \mathrm{l}$ aliquots of supernatant. The mixture was heated at $95^{\circ} \mathrm{C}$ for $30 \mathrm{~min}$, and the reaction was stopped by placing the reaction tubes in an ice bath. The thiobarbituric acid-malondialdehyde (TBA-MDA) complex absorption was measured at $532 \mathrm{~nm}$ and corrected for non-specific turbidity at $600 \mathrm{~nm}$. The concentration of MDA was calculated using a molar extinction coefficient of $155 \mathrm{nM}^{-1} \mathrm{~cm}^{-1}$ [26]. Each data point represents the mean $\pm S D$ of five measurements.

\section{Separation and identification of phospholipids}

The samples (5 g each) of needles were ground to powder in liquid nitrogen, and the lipids were extracted with chloroform:methanol $(2: 1, \mathrm{v}: \mathrm{v})$, according to Juaneda and Requelin [27] and Nichols et al. [28]. The separation of polar and neutral lipids was performed using a SEP-PAK Silica cartridge (Waters As, No. 51900) [29]. The phospholipids were fractionated by TLC on silica gel 60 plates in chloroform:methanol:acetic acid:water (85:15:10:3.5, v/v) [30]. The classes of phospholipids were identified and determined as inorganic Pi, according to the method of Pukacki and KamińskRożek [31]. The quantities of particular phospholipids were

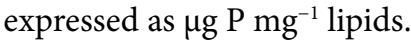

\section{Free fatty acids (FFA), $\boldsymbol{a}$-tocopherol and sterols}

Free fatty acids and $\alpha$-tocopherol were assayed in the total fraction of the lipid extract according to Pukacki and KamińskaRożek [31] after sylilation by N-O-bis-trimethylsilyltrifluoro-acetimide (BSTFA) with heptadecanoic acid (C17) and a-cholestin as internal standards. The samples were separated by gas chromatography (Hewlett Packard 5890) with a capillary column SPB-1, an injector and flame ionization detector temperature of $280^{\circ} \mathrm{C}$, a split injector, and a carrier gas (helium) linear flow rate of $2 \mathrm{~cm}^{3} \mathrm{~min}^{-1}$. FFA, $\alpha$-tocopherol and sterols were identified by comparing the retention times with those of authentic standards obtained from Sigma-Aldrich. The operating conditions were as follows: column temperature $160-280^{\circ} \mathrm{C}$; rate $4^{\circ} \mathrm{C} \mathrm{min}^{-1}$.

\section{Statistical analysis}

The data are presented as the means $\pm S D$. The significance of the differences between the control and stressed plants were assessed on the basis of the analysis of one-way variance (ANOVA) and linear regression for each parameter. Significant differences between the means were determined using Duncan's multiple range test, and the significance levels are indicated as $P<0.05$. Analyses of variance and correlations between variables were performed using the statistical software Statgraphics Plus. For all correlation analyses, the percentages were transformed (arcsin) so that the data conformed to parametric test assumptions.

\section{Results}

\section{Changes in freezing tolerance, MP and water relations during reacclimation/deacclimation}

At the beginning of this study, the spruce seedlings were in the spring deacclimation period. The maximum and minimum temperatures of March were above zero (Fig. 1a). The freezing tolerance $\left(L T_{50}\right)$ of 1-year-old needles was $-17.6^{\circ} \mathrm{C}$. After $18 \mathrm{~d}$ of cold reacclimation, the freezing tolerance of the needles significantly increased from $-17.6^{\circ} \mathrm{C}$ to $-22^{\circ} \mathrm{C}$ (Fig. 1b), while in the control seedlings that were kept outdoors, it decreased to $-11.5^{\circ} \mathrm{C}$ and then continued to decrease to $-7.0^{\circ} \mathrm{C}$ until May. The increase of the freezing tolerance after $18 \mathrm{~d}$ of the seedling needles under reacclimation was accompanied by a significant increase of MP (Fig. 2a), and decrease of the water potential of the shoots $\left(\Psi_{\text {w shoot }}\right)$ from $-0.32 \mathrm{MPa}$ to $-0.64 \mathrm{MPa}$ and $-72 \mathrm{MPa}$, respectively (Fig. 2b), and a decrease of the water content in the needles from $53 \%$ to $48 \%$ and $43 \%$, respectively (Fig. $2 \mathrm{c}$ ). After $18 \mathrm{~d}$ of reacclimation, the needles reached the highest level of membrane permeability to ions, which was increased two-fold (from 132 to $272 \mu \mathrm{S} \mathrm{g}^{-1} \mathrm{FW}$ ) relative to the control seedlings that were kept outdoors (Fig. 2a).

During deacclimation, when the seedlings were returned to the outdoors the values of the water potential of the shoots and the water content, as well as membrane permeability gradually returned to the values of the control samples. However, the freezing tolerance of the seedlings was still higher than that of the non-reacclimated controls. The degree of freezing tolerance in the reacclimation seedlings after 24 days of deacclimation was $4^{\circ} \mathrm{C}$ higher relative to the control seedlings kept outdoors (Fig. 1b). Here, a significant positive correlation between the $L T_{50}$ of the seedlings during deacclimation and the average daily air temperature $(r=0.535, P<0.03)$ was observed using linear regression.

\section{Phospholipids, a-tocopherol, sterols, and lipid peroxidation}

To examine the changes in the structure of membranes in the needles of spruce seedlings subjected to reacclimation, analyses of the amounts of total and individual phospholipids were performed. After 12 days of reacclimation, when the water potential of shoots decreased to $-0.64 \mathrm{MPa}$ (Fig. 2b) in needles, a significant increase in the total phospholipids was observed: $11 \%$ compared to the control $(P<0,05$; Tab. 1$)$. The levels of particular phospholipids (PC, PG, PE and PA) also increased (77\%, 54\%, 30\% and 87\%, respectively; Tab. 2). After 18 days of reacclimation, a continued increase in the phospholipids was observed but to a lesser extent ( $9 \%$ compared to the control seedlings kept outdoors). During deacclimation, decreases in the total and individual phospholipid contents were observed 


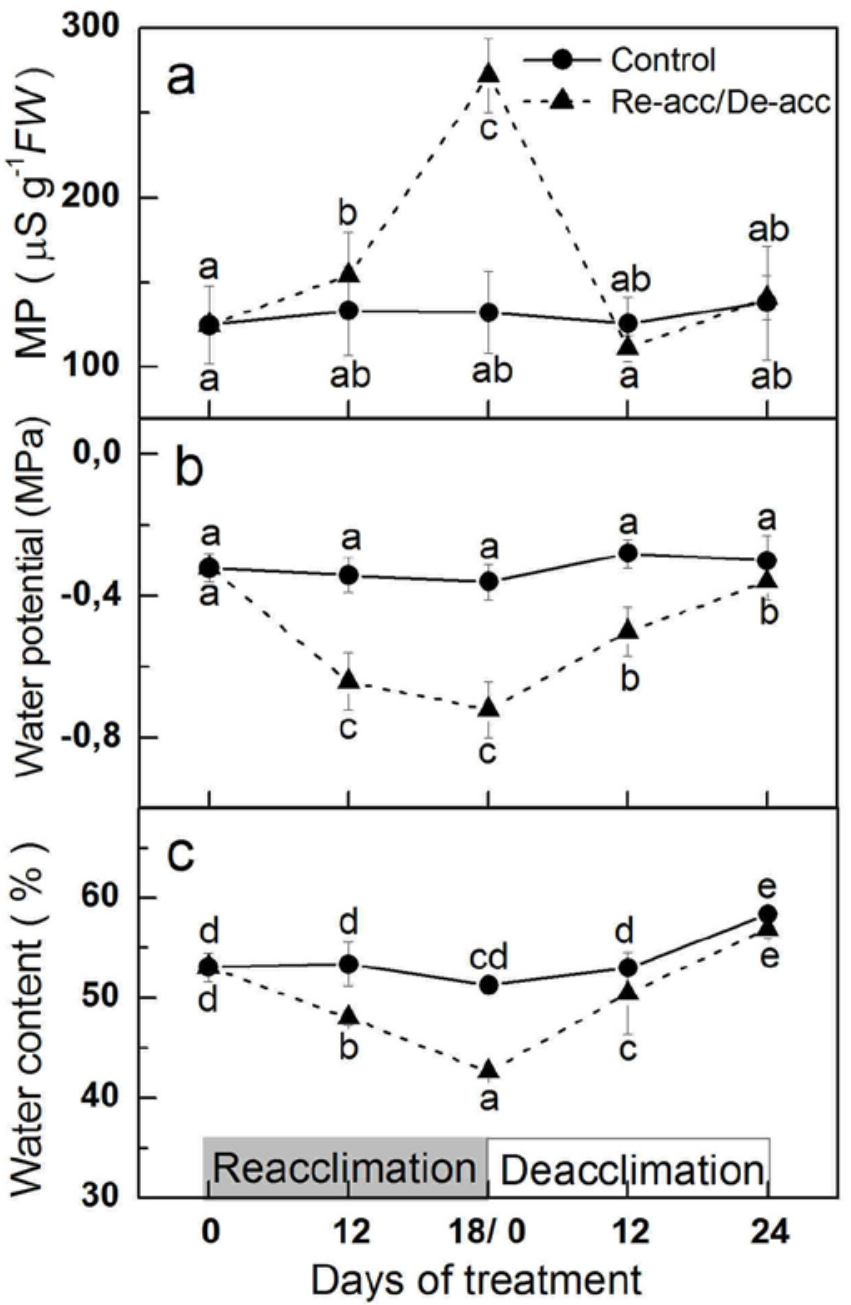

Fig. 2 Effects of reacclimation (Re-acc) and deacclimation (De-acc) in spring on the following: membrane permeability of current-year needles of spruce seedlings (a), shoot water potential (b), and water content in needles (c). Mean values $\pm S D(n=5)$. Significant differences (according to the Duncan test, $P<0.05$ ) are indicated by different letters. MP - membrane permeability. simultaneously with an increase in the water potential of the seedling shoots (Fig. 2b, Tab. 1, Tab. 2). A significant, negative correlation was found between the membrane permeability to ions and the water content in the needles and the water potential in the shoots $\left(\Psi_{\text {w shoot }}\right): r=-0.66(P<0.0003)$ and $r=-0.55(P<0.004)$, respectively (Tab. 3$)$. As well a significant negative correlation was found between the freezing tolerance of the needles and the total phospholipid contents: $r=-0.71$, $-0.74,-0.59$ and -0.74 for PC, PG, PE and PA, respectively $(P<0.001$; Tab. 3$)$. However, a positive correlation was found between the contents of individual phospholipids and membrane permeability: $r=0.49,0.53$ and 0.58 for PC, PG, and PA, respectively $(P<0.01$; Tab. 3$)$. During the reacclimation of spruce seedlings, the contents of free fatty acids (FFA) did not change significantly; only an increase in $\alpha$-tocopherol was noted after $18 \mathrm{~d}$ of reacclimation (from 2.04 to $2.72 \mathrm{ng} \mathrm{g}^{-1} \mathrm{DW}$ ) and in the content of sterols after 12 days of deacclimation (from 2.64 to $3.80 \mathrm{nmol} \mathrm{mg} \mathrm{m}^{-1} \mathrm{DW}$; Tab. 1). Lipid peroxidation, as measured by malondialdehyde (MDA) levels, during the treatment was generally consistent $\left(1.19-1.48 \mathrm{nmol} \mathrm{mg}^{-1} \mathrm{DW}\right)$, irrespective of the reacclimation/deacclimation of the seedling needles.

\section{Discussion}

In late winter post-dormancy, plants can be easily de-hardened [32]. Alternatively, repeated decreases in air temperature at night to several degrees below $0^{\circ} \mathrm{C}$ can lead to reacclimation or can delay the deacclimation of plants, as shown in the present study. In our earlier studies, which were conducted in autumn and mid-winter, 3-year-old Norway spruce seedlings treated with a constant temperature of $-3^{\circ} \mathrm{C}$ did not increase their freezing tolerance. Only at much lower temperatures $\left(-10^{\circ} \mathrm{C}\right)$ did their freezing tolerance increase by $6^{\circ} \mathrm{C}$. In the present study, which was conducted in early spring, the temperature cycle $4 /-3^{\circ} \mathrm{C}$, day/night, which simulated the conditions occurring in spring, had a positive effect on the reacclimation of Norway spruce seedlings. During $12 \mathrm{~d}$ of cyclically changing temperatures, seedlings showed an increase in freezing tolerance of $7^{\circ} \mathrm{C}$ and were able to withstand a temperature of $-25^{\circ} \mathrm{C}$. Simultaneously, a decrease in the shoot water potential was observed, which could evoke many reactions leading to the increased resistance of cells to frost injury [2].

Tab. 1 The effects of reacclimation $\left(4 /-3^{\circ} \mathrm{C}\right.$, day/night $)$ and deacclimation on total phospholipids, free fatty acids, $\boldsymbol{\alpha}$-tocopherol, sterols and malondialdehyde content of needles of Norway spruce seedlings in spring.

\begin{tabular}{|c|c|c|c|c|c|c|}
\hline $\begin{array}{c}\text { Re-acc/de-acc } \\
\text { (days) }\end{array}$ & Treatment & $\begin{array}{c}\text { PL } \\
\left(\mu \mathrm{g} \mathrm{mg}^{-1} \text { lipids }\right)\end{array}$ & $\begin{array}{c}\text { FFA } \\
\left(\mathrm{ng} \mathrm{g}^{-1} D W\right)\end{array}$ & $\begin{array}{c}\text { a-tocopherol } \\
\left(\mathrm{ng} \mathrm{g}^{-1} \mathrm{DW}\right)\end{array}$ & $\begin{array}{c}\text { Sterols } \\
\left(\mathrm{ng} \mathrm{g}^{-1} D W\right)\end{array}$ & 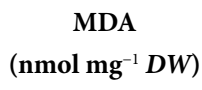 \\
\hline 0 & Control & $6.35 \pm 0.88$ & $3.91 \pm 1.10$ & $2.04 \pm 0.52$ & $3.90 \pm 0.38$ & $1.50 \pm 0.20$ \\
\hline \multirow[t]{2}{*}{12} & Control & $6.31 \pm 0.98$ & $2.98 \pm 0.65$ & $1.90 \pm 0.29$ & $3.10 \pm 0.69$ & $1.07 \pm 0.20$ \\
\hline & Re-acc & $8.05 \pm 0.87^{*}$ & $4.36 \pm 0.99$ & $1.92 \pm 0.12$ & $3.29 \pm 0.50$ & $1.26 \pm 0.10$ \\
\hline \multirow[t]{2}{*}{18} & Control & $6.93 \pm 0.92$ & $3.55 \pm 0.80$ & $2.40 \pm 0.40$ & $3.72 \pm 0.70$ & $0.93 \pm 0.07$ \\
\hline & Re-acc & $7.58 \pm 0.62$ & $2.98 \pm 0.50$ & $2.72 \pm 0.20$ & $3.15 \pm 1.22$ & $1.19 \pm 0.10$ \\
\hline \multirow[t]{2}{*}{12} & Control & $6.33 \pm 0.69$ & $3.12 \pm 0.00$ & $2.05 \pm 0.01$ & $2.64 \pm 0.01$ & $1.15 \pm 0.10$ \\
\hline & De-acc & $6.60 \pm 0.91$ & $2.54 \pm 1.29$ & $2.25 \pm 0.58$ & $3.80 \pm 0.75^{\star}$ & $1.18 \pm 0.30$ \\
\hline \multirow[t]{2}{*}{24} & Control & $5.02 \pm 1.06$ & $3.73 \pm 1.89$ & $2.81 \pm 0.15$ & $3.87 \pm 0.84$ & $1.48 \pm 0.30$ \\
\hline & De-acc & $3.78 \pm 0.80^{*}$ & $3.20 \pm 1.81$ & $2.24 \pm 0.52$ & $3.08 \pm 0.56$ & $1.28 \pm 0.30$ \\
\hline
\end{tabular}

Values are means $\pm S D(n=5)$. Asterisks represent significant differences between treatments in analysis of variance. ${ }^{\star} P<0.05$. De-acc - deacclimation; FFA - free fatty acids; MDA - malondialdehyde; PL - phospholipids; Re-acc - reacclimation. 
Tab. 2 Effects of reacclimation $\left(4 /-3^{\circ} \mathrm{C}\right.$, day/night $)$ and deacclimation on individual phospholipids content of needles of Norway spruce seedlings in spring.

\begin{tabular}{|c|c|c|c|c|c|c|}
\hline \multirow{2}{*}{$\begin{array}{c}\text { Re-acc/de-acc } \\
\text { (days) }\end{array}$} & \multirow[b]{2}{*}{ Treatment } & PI & PC & PG & PE & PA \\
\hline & & \multicolumn{5}{|c|}{ ( $\mu \mathrm{g} \mathrm{mg}^{-1}$ lipids) } \\
\hline 0 & Control & $0.37 \pm 0.06$ & $2.19 \pm 0.22$ & $1.21 \pm 0.12$ & $1.24 \pm 0.19$ & $0.58 \pm 0.11$ \\
\hline \multirow[t]{2}{*}{12} & Control & $0.75 \pm 0.20$ & $1.53 \pm 0.49$ & $0.74 \pm 0.14$ & $1.02 \pm 0.23$ & $0.63 \pm 0.16$ \\
\hline & Re-acc & $0.89 \pm 0.12$ & $2.72 \pm 0.38^{\star *}$ & $1.14 \pm 0.17^{\star}$ & $1.33 \pm 0.19^{* *}$ & $1.18 \pm 0.12^{\star \star}$ \\
\hline \multirow[t]{2}{*}{18} & Control & $0.41 \pm 0.11$ & $2.35 \pm 0.28$ & $0.93 \pm 0.29$ & $0.90 \pm 0.25$ & $1.02 \pm 0.13$ \\
\hline & Re-acc & $0.35 \pm 0.03$ & $2.79 \pm 0.25$ & $1.69 \pm 0.24^{* *}$ & $1.12 \pm 0.19$ & $1.29 \pm 0.16^{*}$ \\
\hline \multirow[t]{2}{*}{12} & Control & $0.37 \pm 0.09$ & $2.09 \pm 0.22$ & $0.75 \pm 0.07$ & $0.74 \pm 0.05$ & $0.75 \pm 0.14$ \\
\hline & De-acc & $0.35 \pm 0.07$ & $2.09 \pm 0.30$ & $1.16 \pm 0.20^{*}$ & $0.80 \pm 0.20$ & $0.83 \pm 0.16$ \\
\hline \multirow[t]{2}{*}{24} & Control & $0.22 \pm 0.08$ & $1.35 \pm 0.26$ & $0.62 \pm 0.08$ & $0.55 \pm 0.14$ & $0.39 \pm 0.09$ \\
\hline & De-acc & $0.19 \pm 0.05$ & $0.97 \pm 0.12$ & $0.37 \pm 0.12^{*}$ & $0.32 \pm 0.05$ & $0.22 \pm 0.04$ \\
\hline
\end{tabular}

Values are means $\pm S D(n=5)$. Asterisks represent significant differences between treatments in analysis of variance as follows: ${ }^{*} P<0.05 ;{ }^{* *}$ $P<0.01$. De-acc - deacclimation; FFA - free fatty acids; MDA - malondialdehyde; PA - phosphatidic acid; PC - phosphatidylcholine; PE phosphatidylethanolamine; PG - phosphatidylglycerol; PI - phosphatidylinositol; Re-acc - reacclimation.

The freezing tolerance of the spruce needles was strongly related to water content during the reacclimation/deacclimation development. The spruce seedlings subjected to reacclimation at $\Psi_{\text {w shoot }}=-0.64 \mathrm{MPa}$ (after $12 \mathrm{~d}$ ) showed an increase in freezing tolerance. After reacclimation, during the deacclimation of seedlings in the open air, as the mean daily air temperature, day length and $\Psi_{\text {w shoot }}$ increased, the freezing tolerance of the spruce seedlings decreased. After deacclimation (24 d) when $\Psi_{\text {w shoot }}$ of the seedlings increased to $0.36 \mathrm{MPa}$, the freezing tolerance of the seedlings that were previously subjected to reacclimation reached $-11.3^{\circ} \mathrm{C}$, while in the control seedlings that were kept outdoors, the freezing tolerance reached only $-7.0^{\circ} \mathrm{C}$. The extent and rate of deacclimation depends not only on the magnitude of the increase in temperature but also on the duration of exposure [2]. The plants subjected to reacclimation followed by spring deacclimation, proceeded more slowly in the de-hardening process, and their freezing tolerance, even after 24 days, was $4.3^{\circ} \mathrm{C}$ higher than that of the control seedlings kept outdoors. This suggests that reacclimation enables the maintenance of higher cold freezing tolerance during deacclimation, which is observed in late spring.

The association of acclimation and spring deacclimation with the lipid composition of cytoplasmic membranes was

Tab. 3 The correlation coefficients $(r)$ values for the freezing tolerance $\left(T K_{50}\right)$, membranes permeability (MP) and water potential $\left(\Psi_{\text {w shoot }}\right)$, water content $(W C)$, total phospholipids (PL), phosphatidylcholine (PC), phosphatidylglycerol (PG), phosphatidic acid (PA) content.

\begin{tabular}{ccccc} 
& \multicolumn{2}{c}{$\boldsymbol{T K}_{50}$} & \multicolumn{2}{c}{ MP } \\
\cline { 2 - 5 } Parameters & $\boldsymbol{r}$ & $\boldsymbol{P}$-value & $\boldsymbol{r}$ & $\boldsymbol{P}$-value \\
\hline$\Psi_{\text {w shoot }}$ & 0.580 & 0.02 & -0.554 & 0.004 \\
$W C$ & 0.665 & 0.0003 & -0.665 & 0.0003 \\
PL & -0.715 & 0.0001 & 0.371 & 0.06 \\
PC & -0.747 & 0.0009 & 0.493 & 0.01 \\
PG & -0.593 & 0.0001 & 0.531 & 0.006 \\
PA & -0.743 & 0.0001 & 0.585 & 0.002 \\
\hline
\end{tabular}

Significance level $(P<0.01)$ of values are shaded. observed by Yoshida and Uemura [18] and Zwiazek et al. [21]. From previous studies, much more is known about the correlation between plant acclimation in autumn than the correlation between spring deacclimation and the content or composition of phospholipids [16]. In isolated thylakoids of $P$. sylvestris needles, a two-fold increase of galactolipids and sulfolipids was observed during autumn, while MGDG (monogalactosylidiacylglyceride) decreased during early winter and DGDG (digalactosyldiacylglyceride) and sulfolipids remained high during winter, decreasing to low levels in spring [33]. In Populus in autumn, a correlation between an increase in freezing resistance and an increase in phospholipid content (mainly PC and PE) was observed by Yoshida and Sakai [34]. In our study, we paid special attention to changes in membrane phospholipids during spring reacclimation/deacclimation, which preceded bud opening. A significant correlation was observed between the freezing tolerance of the seedlings and PL content $(r=-0.71$, $P=0.0002)$. The same trend was visible between needle freezing hardiness and PC content of membranes. In the needles of Norway spruce seedlings, along with a decline in $\Psi_{w \text { shoot }}$ to $-0.64 \mathrm{MPa}$ (after $12 \mathrm{~d}$ of reacclimation), the PL content increased by $28 \%$ and the levels of individual phospholipids (PC, PG, PE and PA) increased from $30 \%$ to $87 \%$. Changes in the lipid content of membranes in plants at low temperatures as well as disturbances in cell ion metabolism may lead to the activation of lipolytic enzymes, such as phospholipase D [35], which is active even at $-20^{\circ} \mathrm{C}$ and causes PC degradation to generate phosphatidic acid and a free headgroup [15]. Wang et al. [36] detected the activity of phospholipases A and D during acclimation. In this study, a significant increase in PC and PA levels in the seedlings subjected to reacclimation was observed after only 12 days of treatment (when $\Psi_{\text {w shoot }}=-0.64 \mathrm{MPa}$ ). The increase in PA may indicate an increase in the degradation of $\mathrm{PC}$ and also in the activity of phospholipase D [37]. However, the conditions of reacclimation to which they were exposed affected PC accumulation to a larger extent than is possible due to enzymatic degradation [37].

During deacclimation, along with the increase in $\Psi_{\text {w shoot }}$, a decrease in the phospholipid content of the needles was observed. The acclimation of Salix phloem parenchyma and spruce needles was associated with metabolic changes in lipids $[3,38]$. In general, 
membrane lipid changes are largely a reversal of those observed during autumnal acclimation. A tendency for such changes in membrane lipids in spring can be explained by the decomposition of phospholipids into simpler compounds, followed by the use of these compounds for the synthesis of important metabolites during plant growth initiation [20]. Sometimes, the freezing stress caused by frost desiccation leads to phospholipid degradation (peroxidation) [39,40]. Fatty acid peroxidation is significantly limited by the cell's antioxidant system, initially by low-molecular-weight compounds, mainly glutathione and ascorbate $[18,40,41]$. Changes in $\alpha$-tocopherol levels have not previously been measured during the reacclimation/deacclimation of Picea needles. Our analyses did not detect peroxidation, and no effect on the levels of free fatty acids, malondialdehyde or $a$-tocopherol was observed during the reacclimation/deacclimation experiment. Thus, the increase in the MP to ions was caused by changes in phospholipid content and most likely by phase changes in the membrane structure $[11,39,40]$. The MP to ions and water is affected by the composition and content of phospholipids (mainly PC) and their fatty acids, chiefly linolenic acid $(18: 3)$ [42,43]. In this study, significant correlations were observed between the MP to ions and the concentrations of three phospholipids: PC, PG and PA. It is interesting that changes in MP are reversible in the reacclimation/deacclimation cycle. Membranes permeability is also affected by sterols [44], which are important components involved in membrane stabilization. In spruce seedlings, no such relationship was observed, as the $\Psi_{\text {w shoot }}$ decreased during reacclimation, while sterol content did not change. However, during the increase in $\Psi_{w \text { shoot }}$ to -0.50 $\mathrm{MPa}$ (during the first days of deacclimation), the sterol content increased relative to the control. It has been suggested that cold hardiness is a function of membrane lipid fluidity and/or the transition temperatures of the solid and gel phases.

Our research showed that reacclimation caused a decrease in the water content of the seedling needles and in the $\Psi_{\text {w shoot }}$ of the seedlings. In this phase state, the MP to ions increased almost 2-fold compared to control seedlings. This phenomenon depends on the deficit of water vapor compressibility in extracellular spaces and on MP. In this study, negative correlations were observed between the MP to ions and both the water content of the needles and $\Psi_{\text {w shoot }}$. Complete rehydration of the tissues was observed at the end of the deacclimation period. Water conditions are important factors that determine the acclimation and cold hardiness of woody plants $[2,45]$. Tissue moisture can also impact hardiness transitions via mechanisms distinct from the effect tissue moisture on extracellular freezing. Needle dehydration significantly decreases the temperature of ice nucleation in extracellular spaces. Additionally, an increase in MP during acclimation and reacclimation is favorable for spruce needles, as it facilitates the leaking of water out of the cytoplasm and protects plants against dangerous intracellular crystallization [21]. If the snow cover in winter is absent, the frost period is prolonged and the air humidity is low, allowing the dangerous process of frost desiccation to take place [22], which degrades the membrane structure. However, as shown by our earlier research [18] and that of other authors [7,19], cytoplasmic membranes are not always injury under such conditions. According to Christersson and Fircks [22], the severity of the injury depends to a large extent on the species and the progress of acclimation.

Because the seedlings subjected to reacclimation increased their freezing tolerance by several degrees and $\Psi_{\text {w shoot }}$ reached $-0.64 \mathrm{MPa}$ despite the gradual increase in day length (14 to 16 hours), it can be assumed that the reacclimation was caused mainly by the low temperature of $-3^{\circ} \mathrm{C}$. Welling et al. [45], who studied downy birch during spring deacclimation, showed that the dormancy release is conditioned mainly by temperature and, less strongly, by photoperiod. In autumn, inverse relations are observed. Christersson [46] reports that in seedlings of P. sylvestris in autumn, short days were more effective than low temperatures.

Earlier research by Welling et al. [47] on hybrid cuttings (Populus tremula $\times$ P. tremuloides Michx.) with a gene (phytochrome A) that blocked reactions of growth inhibition by short days, showed that in autumn, short days and low temperature independently induce cold acclimation. Thus, in species of the genera Pinus and Picea of boreal coniferous forests, different mechanisms can function in autumn and spring to induce the processes of acclimation and deacclimation. Differences in acclimation and deacclimation kinetics may be related to divergent energy requirements. Acclimation involves changes in structure and function, necessitating large amounts of energy. Deacclimation, however, may be a relatively less energy-intensive process [2]. In this study, the seedlings of $P$. abies were obtained from a submontane population (altitude $750 \mathrm{~m}$ a.s.l.) and initiated growth in spring several days later than seedlings originating from lowlands [48]. Our results supplement the current knowledge of this phenomenon, as these results showed that spruce seedlings during spring deacclimation have a potential for reacclimation, which predisposes them to delays in spring growth initiation.

It can be concluded that the processes of cold reacclimation of $P$. abies seedlings in spring are induced mainly by low temperature and are not strongly related to photoperiod. These processes are associated with cold-induced biochemical and biophysical membrane alterations, particularly with changing concentrations of phospholipids in membranes and membrane permeability to ions in needles, which may affect the state of the water conditions in tissues as well as freezing tolerance. The potential of evergreen trees to undergo cold reacclimation in spring under the influence of late spring frosts is favorable, as it enables those species to initiate growth and development without frost damage during cold snaps.

\section{Acknowledgments}

We wish to thank Mariola Matelska for excellent laboratory assistance. This research was supported in part by the Polish Ministry of Sciences and Education, grants: No. 3 P06L 22021 24 and No. N N309 101836 (to PMP).

\section{Authors' contributions}

The following declarations about authors' contributions to the research have been made: planned the experiments and supervised biochemical analyses, contributed to data interpretation and prepared the manuscript: PMP; performed chemical and biochemical determinations: EKR.

\section{References}

1. Kacperska A. Plant responses to low temperature: signalling pathways involved in plant acclimation. In: Margesin R, Schinner F, editors. 
Cold-adapted organisms: ecology, physiology, enzymology and molecular biology. Dusseldorf: Springer; 1999. p. 79-103.

2. Kalberer SR, Wisniewski M, Arora R. Deacclimation and reacclimation of cold-hardy plants: current understanding and emerging concepts. Plant Sci. 2006;171(1):3-16. http://dx.doi.org/10.1016/j.plantsci.2006.02.013

3. Welling A, Palva ET. Molecular control of cold acclimation in trees. Physiol Plant. 2006;127(2):167-181. http://dx.doi. org/10.1111/j.1399-3054.2006.00672.x

4. Søgaard G, Granhus A, Johnsen $\emptyset$. Effect of frost nights and day and night temperature during dormancy induction on frost hardiness, tolerance to cold storage and bud burst in seedlings of Norway spruce. Trees. 2009;23(6):1295-1307. http://dx.doi.org/10.1007/s00468-009-0371-7

5. Repo T. Rehardening potential of Scots pine seedlings during dehardening. Silva Fennica. 1991;25(1):13-21.

6. Leinonen I, Repo T, Hänninen H. Changing environmental effects on frost hardiness of Scots pine during dehardening. Ann Bot. 1997;79(2):133-137. http://dx.doi.org/10.1006/anbo.1996.0321

7. Levitt J. Responses of plants to environmental stresses: water, radiation, salt, and other stresses. 2nd ed. New York NY: Academic Press; 1980. (vol 1).

8. Glerum C. Frost hardiness of coniferous seedlings: principles and applications. In: Duryea ML, editor. Evaluating seedling quality: principles, procedures, and predictive abilities of major tests. Corvallis OR: Forest Research Laboratory, Oregon State University; 1985. p. 107-123.

9. Pukacki P. Freezing tolerance of Polish Norway spruce provenances. Arbor Kórnickie. 1982;26:149-159.

10. Pukacki P, Pukacka S. Freezing stress and membrane injury of Norway spruce (Picea abies) tissues. Physiol Plant. 1987;69(1):156-160. http:// dx.doi.org/10.1111/j.1399-3054.1987.tb01960.x

11. Steponkus PL. Role of the plasma membrane in freezing injury and cold acclimation. Annu Rev Plant Physiol. 1984;35(1):543-584. http://dx.doi. org/10.1146/annurev.pp.35.060184.002551

12. Siminovitch D, Rheaume B, Pomeroy K, Lepage M. Phospholipid, protein, and nucleic acid increases in protoplasm and membrane structures associated with development of extreme freezing resistance in black locust tree cells. Cryobiology. 1968;5(3):202-225. http://dx.doi.org/10.1016/ S0011-2240(68)80164-6

13. Senser M, Beck E. Frost resistance in spruce [Picea abies (L.) Karst.]: IV. The lipid composition of frost resistant and frost sensitive spruce chloroplasts. Z Pflanzenphysiol. 1982;105(3):241-253. http://dx.doi.org/10.1016/ S0044-328X(82)80018-4

14. Senser M, Beck E. Frost resistance in spruce [Picea abies (L.) Karst.]: V. Influence of photoperiod and temperature on the membrane lipids of the needles. Z Pflanzenphysiol. 1982;108(1):71-85. http://dx.doi.org/10.1016/ S0044-328X(82)80092-5

15. Iivonen S, Saranpää P, Sutinen ML, Vapaavuori E. Effects of temperature and nutrient availability on plasma membrane lipid composition in Scots pine roots during growth initiation. Tree Physiol. 2004;24(4):437-446. http://dx.doi.org/10.1093/treephys/24.4.437

16. Selstam E, Öquist G. Effects of frost hardening on the composition of galactolipids and phospholipids occurring during isolation of chloroplast thylakoids from needles of scots pine. Plant Sci. 1985;42(1):41-48. http:// dx.doi.org/10.1016/0168-9452(85)90026-3

17. Yoshida S, Uemura M. Responses of the plasma membrane to cold acclimation and freezing stress. In: Larsson C, Møller IM, editors. The plant plasma membrane: structure, function and molecular biology. Berlin: Springer-Verlag; 1990. p. 293-319.

18. Kamińska-Rożek E, Pukacki PM. Effect of freezing desiccation on cold hardiness, ROS, membrane lipid levels and antioxidant status in spruce seedlings. Acta Soc Bot Pol. 2005;74:219-228.

19. Larcher W. Physiological plant ecology: ecophysiology and stress physiology of functional groups. Berlin Heidelberg: Springer; 2003.

20. Kedrowski RA. Changes in cold hardiness of introduced and native interior Alaskan evergreens in relation to water and lipid content during spring dehardening. Physiol Plant. 1980;48(3):438-442. http://dx.doi. org/10.1111/j.1399-3054.1980.tb03282.x

21. Zwiazek JJ, Renualt S, Croser C, Hansen J, Beck E. Biochemical and physiological changes in relation to cold hardiness. In: Bigras FJ, Colombo SJ, editors. Conifer cold hardiness. Dordrecht: Kluwer Academic Publishers; 2001. p. 165-186.

22. Christersson L, Von Fircks H. Frost and winter desiccation as stress factors. Aquilo Ser Bot. 1990;29:13-19.

23. Pukacki PM, Przybył K. Frost injury as a possible inciting factor in bud and shoot necroses of Fraxinus excelsior L. J Phytopathol. 2005;153(9):512-516. http://dx.doi.org/10.1111/j.1439-0434.2005.01010.x

24. Zwiazek JJ, Shay JM. The effects of sodium fluoride on cytoplasmic leakage and the lipid and fatty acid composition of jack pine (Pinus banksiana) seedlings. Can J Bot. 1988;66(3):535-541. http://dx.doi.org/10.1139/b88-076

25. Boyer JS. Measuring the water status of plants and soils. San Diego CA: Academic Press; 1995.

26. Heath RL, Packer L. Photoperoxidation in isolated chloroplasts: I. Kinetics and stoichiometry of fatty acid peroxidation. Arch Biochem Biophys. 1968;125(1):189-198. http://dx.doi.org/10.1016/0003-9861(68)90654-1

27. Juaneda P, Rocquelin G. Rapid and convenient separation of phospholipids and non phosphorus lipids from rat heart using silica cartridges. Lipids. 1985;20(1):40-41. http://dx.doi.org/10.1007/BF02534360

28. Nichols BW, Harris RV, James AT. The lipid metabolism of blue-green algae. Biochem Biophys Res Commun. 1965;20(3):256.

29. Ames DN. Assay of inorganic phosphate, total phosphate and phosphatases. In: Colowick SP, Kaplan NO, editors. Methods in Enzymology. New York NY: Academic Press; 1966. p. 115-118.

30. Pukacki PM, Kendall EJ, McKersie BD. Membrane injury during freezing stress to winter wheat (Triticum aestivum L.) crowns. J Plant Physiol. 1991;138(5):516-521. http://dx.doi.org/10.1016/S0176-1617(11)80233-6

31. Pukacki P, Kamińska-Rożek E. Long-term implications of industrial pollution stress on lipids composition in Scots pine (Pinus sylvestris L.) roots. Acta Physiol Plant. 2002;24(3):249-255. http://dx.doi.org/10.1007/ s11738-002-0048-y

32. Koski V. The timing of hardening and dehardening of forest trees. Acta Hortic. 1985;168:117-123.

33. Oquist G. Seasonally induced changes in acyl lipids and fatty acids of chloroplast thylakoids of Pinus silvestris. A correlation between the level of unsaturation of monogalactosyldiglyceride and the rate of electron transport. Plant Physiol. 1982;69(4):869-875. http://dx.doi.org/10.1104/pp.69.4.869

34. Yoshida S, Sakai A. Phospholipid changes associated with the cold hardiness of cortical cells from poplar stem. Plant Cell Physiol. 1973;14(2):353-359.

35. Kacperska A. Sensor types in signal transduction pathways in plant cells responding to abiotic stressors: do they depend on stress intensity? Physiol Plant. 2004;122(2):159-168. http://dx.doi. org/10.1111/j.0031-9317.2004.00388.x

36. Wang X, Li W, Li M, Welti R. Profiling lipid changes in plant response to low temperatures. Physiol Plant. 2006;126(1):90-96. http://dx.doi. org/10.1111/j.1399-3054.2006.00622.x

37. Pukacka S. Phospholipase D activity during long-term storage of Acer platanoides seeds in the imbibed state and desiccation of Acer saccharinum seeds. Acta Physiol Plant. 1993;15:147-153.

38. Senser M. Frost resistance in spruce [Picea abies (L.) Karst]: III. Seasonal changes in the phospho- and galactolipids of spruce needles. Z Pflanzenphysiol. 1982;105(3):229-239. http://dx.doi.org/10.1016/ S0044-328X(82)80017-2

39. Kendall EJ, McKersie BD. Free radical and freezing injury to cell membranes of winter wheat. Physiol Plant. 1989;76(1):86-94. http://dx.doi. org/10.1111/j.1399-3054.1989.tb05457.x

40. Griffiths G, Leverentz M, Silkowski H, Gill N, Sánchez-Serrano JJ. Lipid hydroperoxide levels in plant tissues. J Exp Bot. 2000;51(349):1363-1370. http://dx.doi.org/10.1093/jexbot/51.349.1363

41. Munné-Bosch S, Alegre L. Drought-induced changes in the redox state of 
$\alpha$-tocopherol, ascorbate, and the diterpene carnosic acid in chloroplasts of Labiatae species differing in carnosic acid contents. Plant Physiol. 2003;131(4):1816-1825. http://dx.doi.org/10.1104/pp.102.019265

42. Golovina EA, Hoekstra FA, Hemminga MA. Drying increases intracellular partitioning of amphiphilic substances into the lipid phase impact on membrane permeability and significance for desiccation tolerance. Plant Physiol. 1998;118(3):975-986. http://dx.doi.org/10.1104/pp.118.3.975

43. Grunwald C, Saunders PF. Function of sterols (and discussion). Phil Trans R Soc Lond B. 1978;284(1002):541-558. http://dx.doi.org/10.1098/ rstb.1978.0088

44. Wang Y, Zwiazek JJ. Effects of storage temperature on physiological characteristics of fall-lifted white spruce (Picea glauca) bareroot seedlings. Can J For Res. 1999;29(6):679-686. http://dx.doi.org/10.1139/x99-038
45. Welling A, Rinne P, Viherä-Aarnio A, Kontunen-Soppela S, Heino P, Palva ET. Photoperiod and temperature differentially regulate the expression of two dehydrin genes during overwintering of birch (Betula pubescens Ehrh.). J Exp Bot. 2004;55(396):507-516. http://dx.doi.org/10.1093/jxb/erh045

46. Christersson L. The influence of photoperiod and temperature on the development of frost hardiness in seedlings of Pinus silvestris and Picea abies. Physiol Plant. 1978;44(3):288-294. http://dx.doi. org/10.1111/j.1399-3054.1978.tb08634.x

47. Welling A, Moritz T, Palva ET, Junttila O. Independent activation of cold acclimation by low temperature and short photoperiod in hybrid aspen. Plant Physiol. 2002;129(4):1633-1641. http://dx.doi.org/10.1104/pp.003814

48. Giertych M. Genetic variability of Polish spruce [Picea abies (L.) Karst.] races. Arbor Kórnickie. 1976;21:189-211. 